\title{
Influence of the Electrokinetic Injection Conditions on the Separation of DNA Fragments in Capillary Electrophoresis
}

\author{
Jonatan Ricardo Catai and Emanuel Carrilho* \\ Instituto de Química de São Carlos, Universidade de São Paulo, Av. Trabalhador Sãocarlense, 400, \\ CP 780, 13560-970 São Carlos - SP, Brazil
}

\begin{abstract}
Em análises genéticas por eletroforese capilar com soluções poliméricas existem muitas variáveis que afetam a separação dos fragmentos de DNA. Uma das mais críticas é o processo da injeção da amostra, a qual pode afetar consideravelmente a eficiência e a resolução dos picos. Neste trabalho, estudou-se a influência da composição da amostra e as condições da injeção eletrocinética na separação dos fragmentos de DNA em eletroforese capilar com solução polimérica renovável. Os estudos foram realizados injetando-se eletrocineticamente as amostras do DNA sob uma variedade de condições tais como, a força iônica da amostra e sua capacidade tamponante e a qualidade da matriz de separação. Em todos os experimentos, os fragmentos de DNA foram corados com brometo de etídio para detecção por fluorescência induzida a laser e separados sob um campo elétrico de $200 \mathrm{~V} \mathrm{~cm}^{-1}$ em uma coluna capilar revestida com polialcoolvinílico e preenchida com uma solução $0,5 \%$ de hidroxietilcelulose como matriz de separação. Sob estas condições de análise, a composição da amostra deve conter entre 1 e $5 \mathrm{mmol} \mathrm{L}^{-1}$ de tampão de separação para a obtenção de injeções reprodutíveis com um coeficiente de variação menor que $4 \%$ tanto para o tempo de migração quanto para a quantidade de material injetado.
\end{abstract}

In genetic analysis by capillary electrophoresis with polymer solutions there are many variables that affect separation of the DNA fragments. A very critical one is the sample injection process, which can considerably affect the peak efficiency and the resolution. In this work, we have studied the influence of the DNA sample composition and the electrokinetic injection conditions in the separation of DNA fragments by capillary electrophoresis using replaceable polymer solutions. The studies were carried out by electrokinetically injecting the DNA samples under a variety of conditions, such as sample ionic strength, buffering capacity and the quality of the separation matrix. In all experiments DNA was stained with ethidium bromide for laser-induced fluorescence (LIF) detection and separated in a poly (vinylalcohol) coated capillary column filled with $0.5 \%$ hydroxyethylcellulose solution under a $200 \mathrm{~V} \mathrm{~cm}^{-1}$ electric field. Under such conditions, samples prepared with 1 to $5 \mathrm{mmol} \mathrm{L}^{-1}$ of running buffer have been shown to produce reproducible injections with $\mathrm{RSD}<4 \%$ for both migration time and peak area.

Keywords: DNA sizing, polymer solutions, electrokinetic injection, laser-induced fluorescence

\section{Introduction}

Capillary electrophoresis (CE) is a high-resolution separation technique for biomolecules and has faced an exponential growth in the last decade, to a point in which specialized journals dedicate entire issues to review articles and a large number of books have already been published. ${ }^{1}$ (A simple bibliographic retrieval for "capillary electrophoresis" and "review" using the internet yielded several hundred review articles and over forty books). Traditionally, DNA has been analyzed almost exclusively

*e-mail: emanuel@iqsc.usp.br by slab-gel electrophoresis (SGE) and this is still an important tool in biochemistry and molecular biology laboratories all over the world. However, since its earlier stages CE has shown impressive advantages over SGE for the separation of DNA restriction fragments using either gel-filled capillaries ${ }^{2}$ or polymeric solutions $s^{3}$ and it is becoming widely accepted. Analysis and separation of DNA fragments has been performed by CE in a variety of ways. In order to suppress the electroosmotic flow (EOF) generated at the capillary inner walls, permanent $t^{4,5}$ or dynamic coatings ${ }^{6-8}$ can be applied when polymer solutions are used as DNA sieving media. Examples of polymers that have been used as sieving matrices are linear 
poly(acrylamide) ${ }^{9}$ and poly(dimethylacrylamide), ${ }^{10}$ hydroxyethylcellulose, ${ }^{11}$ hydroxypropylcellulose, ${ }^{12}$ poly(dimethylacrylamide-co-beta-D-glucopyranoside), ${ }^{13}$ poly-(ethyleneoxide),$^{14}$ and poly(vinylpyrrolidone), ${ }^{15}$ to name a few. Specific separation goals can be achieved by tailoring electrophoretic conditions and matrix composition. For example, ultra-fast separations can be carried out in short capillaries and high electric fields ${ }^{16}$ or a very large DNA size range can be separated with the appropriate mixture of polymers, ${ }^{17}$ i.e., by manipulating electric field and concentrations it is possible to obtain any degree of base-pair resolution at any given DNA size. ${ }^{18}$ After a systematic study of the separation matrices ${ }^{19,20}$ and of the factors that are relevant for the DNA mobility and its migration mechanism, ${ }^{21,22}$ Heller reviewed all the theoretical and empirical mechanisms of electrophoretic migration of DNA in CE. ${ }^{23}$

A particular aspect of the analysis of DNA in CE is sample introduction. In any mode of CE, the sample can be introduced into the capillary either by hydrodynamic (HD) or electrokinetic (EK) injection. In HD injection the sample is introduced into the capillary by a pressure gradient, which can be positive or negative. It is considered "positive pressure" either when pressure is applied directly over the sample, or when the sample vial is lifted above the electrolyte level (hydrostatic injection). Electrokinetic injection takes place when a voltage is applied to the electrode inside the sample solution driving the analytes to the capillary. ${ }^{24}$ In general, most CE applications use HD injection because it is theoretically well established, has a negligible bias, and can be easily managed. However, HD sample injections can only be made if the separation medium has low viscosity (about that of water). In case of nucleic acids, the separation matrix is rather viscous and inhibits sample injection through pressure application. Therefore, DNA is preferably injected using the EK technique, which shows some advantages, such as detectability enhancement and easy of use. Some disadvantages are also inherent to EK injection, such as the repeatability in EK is lower than in HD for migration time $(0.2-2 \%)$ and for peak area (2-5\%), matrix (separation and sample) effects are important and the electrophoretic mobility is ion selective. ${ }^{24}$ Fortunately, DNA fragments do not suffer from the later effect because every DNA fragment in the buffer solution has the same electrophoretic mobility (the same charge/size ratio) but, depending on the injection conditions (voltage, ionic strength of sample solution, concentration and type of the separation matrix), the DNA can assume different conformations leading to different separation mechanisms. ${ }^{23}$ Such parameters have influence on resolution, time of analysis, and the size range of DNA separation.
We have chosen to study some aspects of DNA injection to maximize the signal-to-noise ratio $(\mathrm{S} / \mathrm{N})$, the peak efficiency, and the resolution. Instinctively, simply by injecting more DNA (e.g., longer injection times) it is straightforward to increase S/N. However, as in chromatography, ${ }^{25}$ a larger amount of injected analyte results in lower efficiency for the separated peaks. The theory predicts that total variance $\left(\sigma_{\text {tot }}^{2}\right)$ of an electrophoretic peak is the contribution of several linear independent variances, ${ }^{16,26}$

$\sigma_{t o t}^{2}=\sigma_{D}^{2}+\sigma_{P}^{2}+\sigma_{\Delta T}^{2}+\sigma_{e o f}^{2}+\sigma_{i n j}^{2}+\sigma_{\text {det }}^{2}+\sigma_{e c}^{2}$

where $\sigma_{D}^{2}$ is the variance due to molecular diffusion, $\sigma_{P}^{2}$ is the variance due to the matrix network dynamic dissociation and polymer DNA interactions, $\sigma_{\Delta T}^{2}$ is the variance due to the temperature profile across the column, $\sigma_{\text {eof }}^{2}$ is the variance due to electroosmotic flow, $\sigma_{i n j}^{2}$ and $\sigma_{\text {det }}^{e f o}$ are the variances due to injection and detection, respectively and $\sigma_{e c}^{2}$ is the variance due to extra column effects. There are other band broadening factors but, in general, they are less important.

The fraction of the total electric current carried by each ionic species in solution during the electrokinetic process can be expressed by the transference number $\left(T_{D N A}\right)^{27}$ which is given by the equation (2):

$T_{D N A}=\frac{C_{D N A} Z_{D N A} \mu_{D N A}}{\sum_{i=1}^{n} C_{i} Z_{i} \mu_{i}}$

where $C, Z$ and $\mu$ are, respectively, the concentration, the charge and the free solution mobility for DNA and for any ion " $i$ ". This equation shows that the injection process should be biased towards faster migrating small ions and shorter DNA fragments (it is necessary to take into account also that DNA samples may contain chloride ions, deoxy and dideoxynucleotides, phosphates, template DNA, primer excess, and other anionic species from buffers). This indicates that the amount of DNA fragments injected could be increased by reducing the concentration of other ionic components of the samples. Furthermore, there are two other important variables which rule the quantity of the DNA loaded into the capillary. They are the injection time and the applied voltage during the EK injection process. The quantity of the analytes injected $\left(n_{a}\right)$ can be expressed by equation $(3):^{24,28}$

$n_{a}=\left(\mu_{a}+\mu_{e o f}\right) r^{2} \pi E_{i n j} t_{i n j} C_{a}$

where $m_{a}$ is the electrophoretic mobility of the analyte, $\mu_{\text {eof }}$ is the EOF mobility, $r$ is the inner radius of the capillary, 
$E_{i n j}$ is the injection electric field strength, $t_{i n j}$ is the injection time and $C_{a}$ is the analyte concentration. However, if a coated capillary column is used, the EOF component is negligible and sample introduction is carried out proportional to the number of coulombs transferred during the EK injection.

In this work the influence of different buffer concentrations of the DNA samples during electrokinetic injection was evaluated in a systematic series of experiments. A number of consecutive injections using the same sample with a new separation matrix for each run, the same separation matrix with new sample for each run, and the same sample with the same separation matrix (i.e., both were held constant for several injections) were evaluated.

\section{Experimental}

\section{Chemicals and solutions}

All buffer constituents, N-tris(hydroxymethyl)methyl3-aminopropanesulfonic acid (TAPS), tris(hydroxymethylaminomethane) (Tris), EDTA, sodium hydroxide and hydroxyethylcellulose (HEC) were purchased from Sigma (St Louis, MO, U.S.A.). A 1-kbp DNA ladder (a mixture of several DNA fragments, with multiples of a thousand base pairs (bp) in size) with fragment sizes of $75,134,154,201$, 220, 298, 344, 396, 506, 517, 1016, 1636, 2036, 3054, $4072,5090,6108,7126,8144,9162,10180,11198$, and 12216 bp was supplied by Gibco (Carlsbad, CA, U.S.A.) and the intercalator ethidium bromide from Molecular Probes (Eugene, OR, U.S.A.). The electrophoresis buffer was $100 \mathrm{mmol} \mathrm{L}^{-1}$ Tris, $100 \mathrm{mmol} \mathrm{L}^{-1}$ TAPS and $2 \mathrm{mmol} \mathrm{L}^{-1}$ EDTA, pH 8.3 (TTE buffer) in deionized water (Milli-Q, Millipore, Bedford, MA, U.S.A). The solution of polymeric sieving agent with $0.5 \% \mathrm{~m} / \mathrm{v}$ hydroxyethylcellulose (HEC) $140-160 \mathrm{kDa}$ was prepared in $100 \mathrm{mmol} \mathrm{L}^{-1}, \mathrm{pH} 8.3$, TTE buffer. All buffer solutions were filtered through a $0.22 \mu \mathrm{m}$ filter (Millipore, Bedford, MA, U.S.A.) and degassed under vacuum.

\section{Capillary electrophoresis apparatus and separation conditions}

All electrophoresis experiments were carried out in a P/ACE 5000 System from Beckman (Fullerton, CA, U.S.A.) equipped with a laser-induced fluorescence (LIF) detection unit, which was controlled via an IBM-compatible PC with System GOLD Software (Beckman) for data acquisition and analysis. Analyte excitation was obtained from a $3 \mathrm{~mW}$ Ar-ion laser $\left(\lambda_{\text {exc }}=488 \mathrm{~nm}\right)$. A $488 \mathrm{~nm}$ laser line rejection filter was placed in the light path to block the scattered laser radiation in conjunction with a $20 \mathrm{~nm}$ bandwidth filter centered at $520 \mathrm{~nm}$ for selection of the fluorescence light. The electrophoresis was carried out in a poly(vinylalcohol) (PVA) coated fused-silica capillary column (kindly donated by Professor Barry L. Karger, from The Barnett Institute, Northeastern University, Boston, MA, U.S.A.). The capillary was $75 \mu \mathrm{m}$ i.d. and $47 \mathrm{~cm}$ in length ( $40 \mathrm{~cm}$ effective length) and was placed inside a cartridge for temperature control. Before each distinct experiment, the PVA-coated capillary column was flushed with deionized water then refilled with the polymer solution with a gas-tight syringe. After each separation-matrix replacement, the column was preelectrophoresed until the background fluorescence and current were stabilized. All separations were carried out at $200 \mathrm{~V} \mathrm{~cm}^{-1}$ and $30^{\circ} \mathrm{C}$ while samples were EK injected at $50 \mathrm{~V} \mathrm{~cm}^{-1}$ for $20 \mathrm{~s}$.

\section{Sample preparation}

Aliquots of $1 \mathrm{mg} \mathrm{mL}^{-1} 1$-kbp DNA ladder were desalted with a Centri•Sep (Princeton Separations, Adelphia, NJ, U.S.A.) spin column according to the manufacturer's protocol. After desalting the DNA was quantitated by UV spectrophotometry and diluted to $100 \mu \mathrm{g} \mathrm{mL}^{-1}$ with either deionized water or concentrated buffer. DNA sample aliquots were prepared with TTE buffer to a final concentration of $1.0,5.0$, and $10.0 \mu \mathrm{mol} \mathrm{L}^{-1}$. All DNA samples were stained with ethidium bromide for LIF detection at a final concentration of $10 \mathrm{mmol} \mathrm{L}^{-1}$ by vortex mixing DNA and intercalator for $30 \mathrm{~s}$, followed by a $30 \mathrm{~min}$ incubation at $40{ }^{\circ} \mathrm{C}$, then placed in ice and kept in the dark.

\section{Factors that affect electrokinetic injection}

The first few exploratory experiments were conducted to evaluate the separation behavior when sample and separation matrix were used under repetitive injections. Several injections using the same sample aliquot and the same polymeric solution in the capillary (matrix was not replaced in between runs) were made. The second step was to determine which part of previous experiment (the sample or polymeric solution) accounted for the effects that were observed, therefore, two other experiments were made. First, six runs were made without replacing the polymeric solution in the capillary, but replacing the sample aliquot for each run, i.e., the polymeric solution was aging and the sample was always fresh. In the second, all six runs were made without replacing the sample aliquot, but replacing the polymeric solution in the capillary, i.e., now the sample was aging and the polymeric solution always renewed. For each run the EK injection was made with $20 \mathrm{~s}$ at $50 \mathrm{~V}$ 
$\mathrm{cm}^{-1}$. The electric field during separation was always 200 $\mathrm{V} \mathrm{cm}^{-1}$. Similar experiments were carried out with the DNA sample being dissolved in the CE buffer, which increased the sample conductivity and the buffering capacity.

\section{Results and Discussion}

The separation of 1-kbp ladder in CE using a dilute polymer solution is particularly interesting. An example of an average separation of the 1-kbp DNA ladder is presented in Figure 1. The separation is characterized by a series of small peaks (fragments smaller than 520 bp coming from the Hinf I DNA expression vector) with increasing height, then, after a short gap, a tall peak appears (peak with 1636 bp from the Hinf I vector) before a series of slightly resolved peaks (the 1-kbp ladder) culminating with a large non-resolved peak. This last peak is normally composed of several fragments larger than a given size, as predicted by the Biased-Reptation Model (BRM). ${ }^{29}$ In the Biased-Reptation regime, all fragments migrate with the same electrophoretic mobility due to the stretching imposed by the high electric field, thus losing size selectivity. In general, detection of DNA with intercalators reveals that the peak height is not only proportional to the DNA quantity but also proportional to the DNA size. This occurs because the intercalators bind DNA in a rough proportion, i.e., if different size fragments were in a mixture at the same concentration, the peak height of each fragment would be proportional to its size.

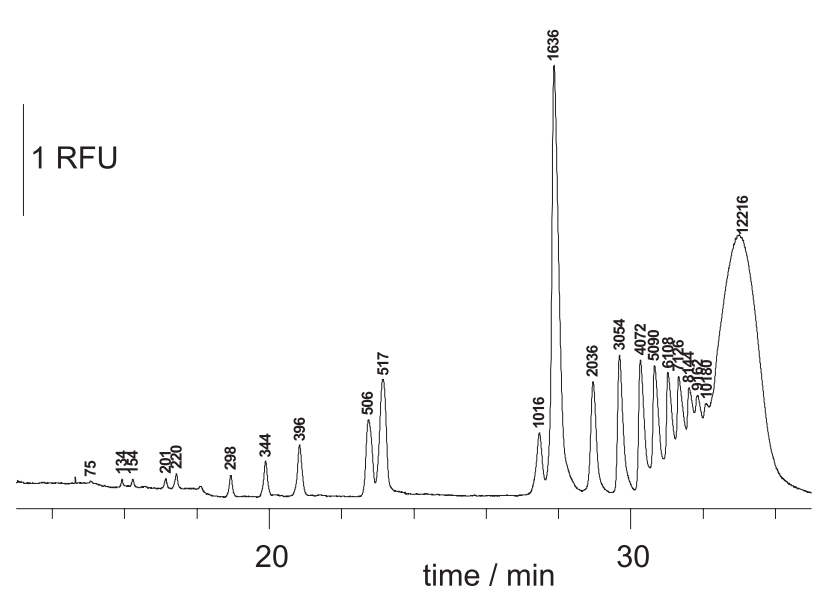

Figure 1. Model separation of 1-kbp DNA ladder in capillary electrophoresis using hydroxyethylcellulose as sieving matrix. A $75 \mu \mathrm{m}$ id PVA coated capillary column with $47 \mathrm{~cm}$ long $(40 \mathrm{~cm}$ effective length) was filled with $0.5 \%$ HEC solution in $100 \mathrm{mmol} \mathrm{L}^{-1} \mathrm{TTE}$ buffer and the separation was carried out with $200 \mathrm{~V} \mathrm{~cm}^{-1}$ electric field. The desalted DNA sample $\left(100 \mu \mathrm{g} \mathrm{mL}^{-1}\right.$ diluted in deionized water) was intercalated with $10 \mu \mathrm{mol} \mathrm{L} \mathrm{L}^{-1}$ of ethidium bromide for LIF detection (emission at $520 \mathrm{~nm}$ ) with an Ar-ion laser (excitation at $488 \mathrm{~nm}$ ), and electrokinetically injected for $20 \mathrm{~s}$ under an electric field of $50 \mathrm{~V} \mathrm{~cm}^{-1}$. The labels on top of the peaks represent the number of base pairs for each peak. RFU: relative fluorescence unit.
The initial motivation that led to this work were the development of a complete study on electrokinetic injection using multivariated optimization such as simplex. ${ }^{30}$ Since a large number of injections would be necessary it was interesting to know whether it would be possible to reuse a sample and even the separation matrix. Obviously, reuse of sample is directly related to the cost of experiments, which is particularly critical in developing countries such as Brazil. Reagents are not always readily available and importation costs are sometimes prohibitive. In this sense, using the same sample aliquot would be beneficial, however, it should not bring about any extraneous effects to the simplex optimization, which would be difficult to account for. In order to evaluate and quantitate the effect of repetitive analysis six injections were performed with the same sample aliquot and the DNA was separated with the same separation matrix. Deionized DNA samples were used to maximize the DNA load according to equation (2). Electrokinetic injection of DNA from a low conductivity medium causes an acceleration of the fragments towards the column entrance where the DNA molecules find a highly-viscous conductive medium. The change in conductivity and viscosity decreases the velocity of the molecules stacking them at the entrance of the column. However, we have observed that the first injection of any aliquot was systematically worse than the following injections of the very same aliquot. The first injection generally yielded small broad peaks while the second one yielded sharp tall peaks as illustrated in Figure 2.

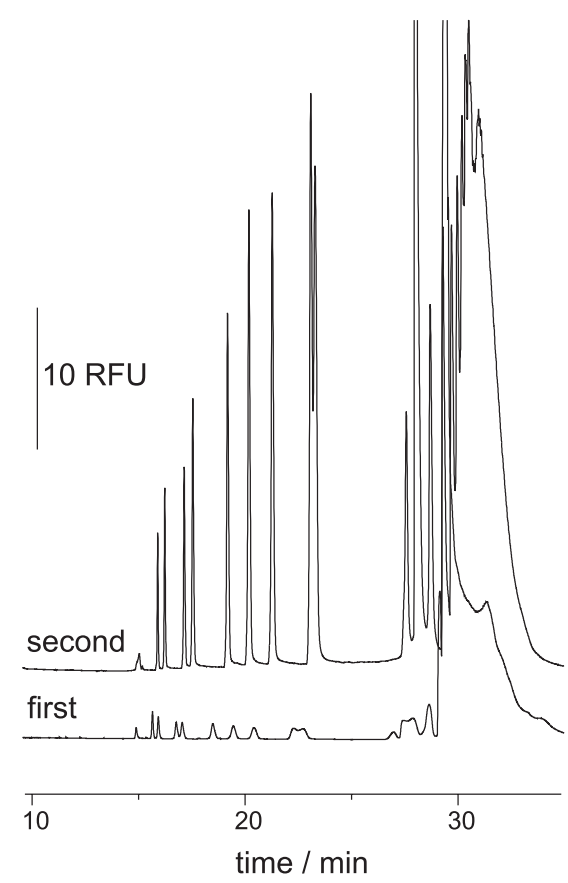

Figure 2. Two consecutive injections of the same sample aliquot of desalted 1-kbp DNA ladder. Analysis conditions are the same as in Figure 1. 
Figure 3 presents the results of six consecutive injections. It is possible to note that from the first through the sixth injection there was a continuous increase in the signal intensity for the smaller (Hinf I) fragments and a relative decrease of the larger 1-kbp fragments. There was an initial decrease in the electrophoretic mobility simultaneous with a decrease in the overall resolution occurring after the fourth injection. In order to better quantitate the differences, the total area and the resolution of the 506/517 bp peaks is plotted as a function of the injection number in Figure 4. Although the area data was scattered in Figure 4A, it was possible to detect a slight increase in the total area, indicating that more DNA was injected in each injection. The resolution of the 506/517 bp peak pair was continuously degraded after the second injection, which presented a slight increase from the first. With the continuous use of the sample, besides electrolysis products, there was an increase in the ionic strength in the sample due to the migration of cations (Tris) leaving the capillary towards the cathode. Also, there is an additional buffer carry-over on the capillary tip from the buffer reservoir thus increasing the conductivity of the sample. The consequence is that the quantity of DNA injected into the column increased. However, according to equation (2), when the ionic concentration is high enough the quantity of the transferred DNA tends to zero. Because of the continuous change in the sample composition, there must

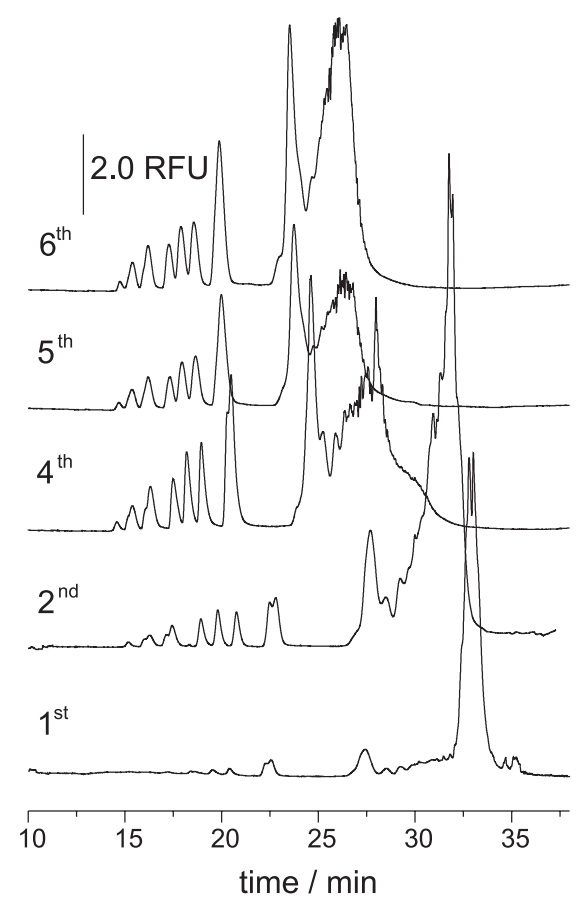

Figure 3. Six consecutive injections of the same sample aliquot of desalted 1-kbp DNA ladder, using the same load of polymer solution inside the capillary. All other conditions are the same as in Figure 1. be a specific condition between the first and the fourth run in which an optimum is reached. This condition is close to that of the second run; the signal was too small in the first one and, for the fourth one, despite the high signal intensity, the resolution was poor. Further investigation on how the sample changes under the electrokinetic injection conditions should be required for proper measurement of the total amount of DNA injected, and the changes in the ionic strength and the $\mathrm{pH}$.
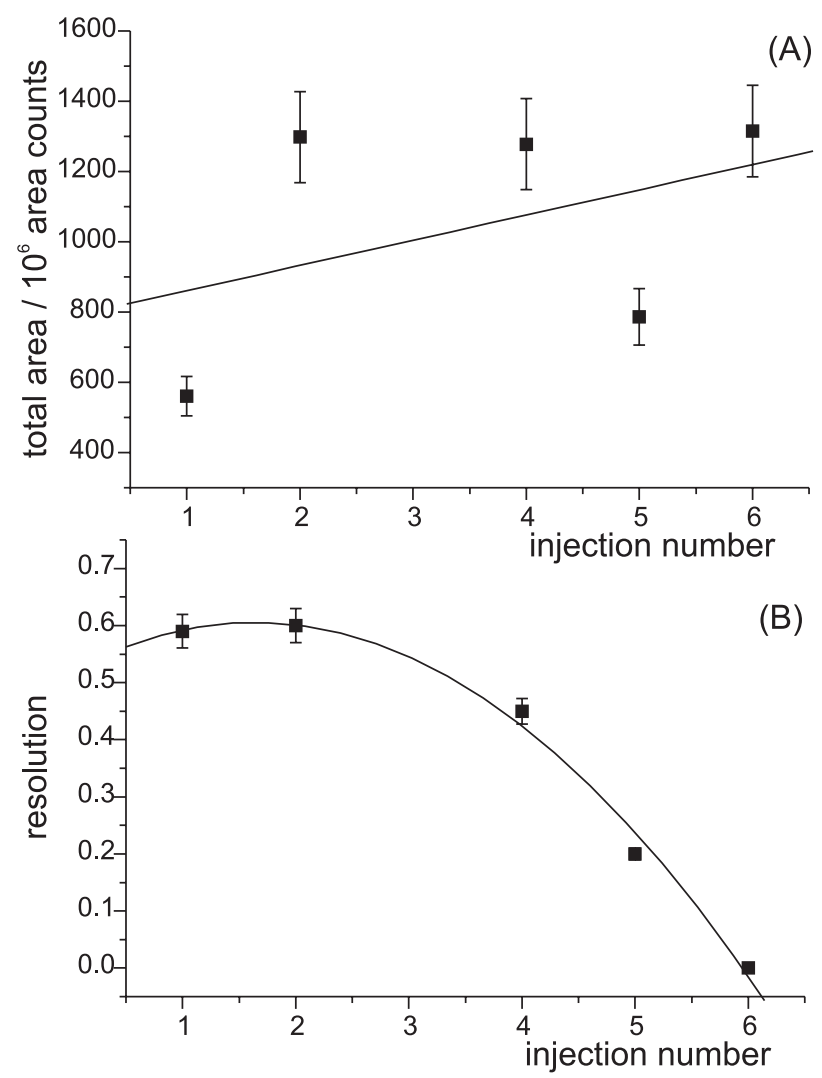

Figure 4. Quantitative evaluation of the quality of the separation after consecutive injections and repetitive use of sample and separation matrix, extracted from data presented in Figure 3. A) Total area counts for all peaks in each electropherogram. B) Resolution for the 506/517 bp peak pair.

\section{Effect of sample ionic strength}

Several experiments at controlled buffer concentration were carried out in order to establish a rugged sample matrix in which the injection-to-injection variability would be as low as possible. An optimized sample matrix should present a buffer concentration not only high enough to produce reproducible consecutive injections but also low enough to yield sufficient signal intensity. The deionized $1 \mathrm{kbp}$ DNA ladder was diluted in concentrated TTE buffer to result in a $100 \mu \mathrm{g} \mathrm{mL}^{-1}$ DNA sample with buffer concentrations of 1.0, 5.0, and $10.0 \mathrm{mmol} \mathrm{L}^{-1}$. 
Quantitative results from the separation of the $1 \mathrm{kbp}$ DNA ladder diluted in separation buffer at four different concentrations are presented in Figure 5. It is clearly seen that the best separation was obtained with the sample containing $5.0 \mathrm{mmol} \mathrm{L}^{-1}$ of buffer. The quality of the separation can be measured by both the resolution of a given pair of peaks (506/517 bp) and the efficiency of selected peaks (396 and $1636 \mathrm{bp}$ ), which are shown in Figure $5 \mathrm{~A}$ and $5 \mathrm{~B}$, respectively. Although $5.0 \mathrm{mmol} \mathrm{L}^{-1}$ presented the best separation parameters, its signal intensity (measured by the total peak area) was smaller than those samples diluted with deionized water (or zero buffer concentration) or $1.0 \mathrm{mmol} \mathrm{L}^{-1}$ of buffer, as expected. The worst signal intensity was obtained with $10 \mathrm{mmol} \mathrm{L}^{-1}$ because the ionic concentration increased so much, diminishing the transference number of DNA. The total peak area for several replicates (from 4 to 6 replicates) is presented in Figure 6. Note that at lower buffer concentrations (deionized sample and $1.0 \mathrm{mmol} \mathrm{L}^{-1}$ ) the standard deviation was very high when compared to the more conductive samples. The solid line was drawn with a Lorentzian peak-fitting tool from Microcal Origin 6.0 and it is just a trend line added for visual aid and holds no statistical significance as a specific function of the buffer
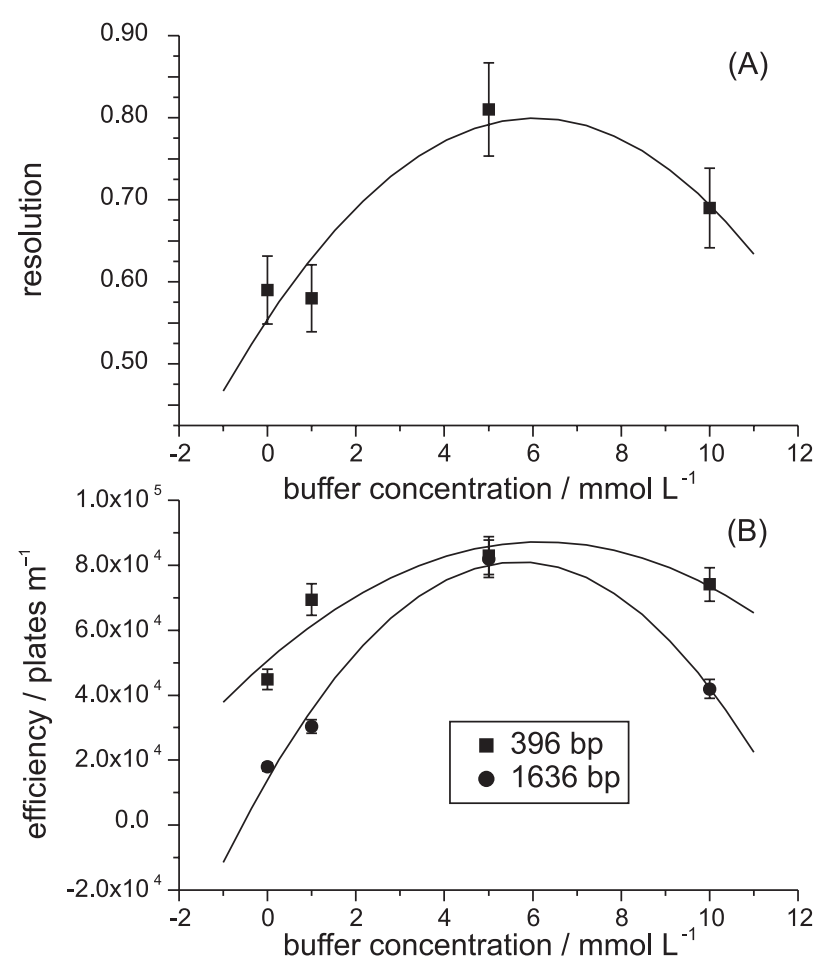

Figure 5. Quantitative evaluation of the quality of the separation as a function of the sample buffer concentration. A) Resolution for the $506 / 517$ bp peak pair. B) Separation efficiency of peaks $396 \mathrm{bp}$ and $1636 \mathrm{bp}$, in plates per meter. Analysis conditions were the same as in Figure 1, except the sample buffer concentration. Separations were carried out in triplicate.

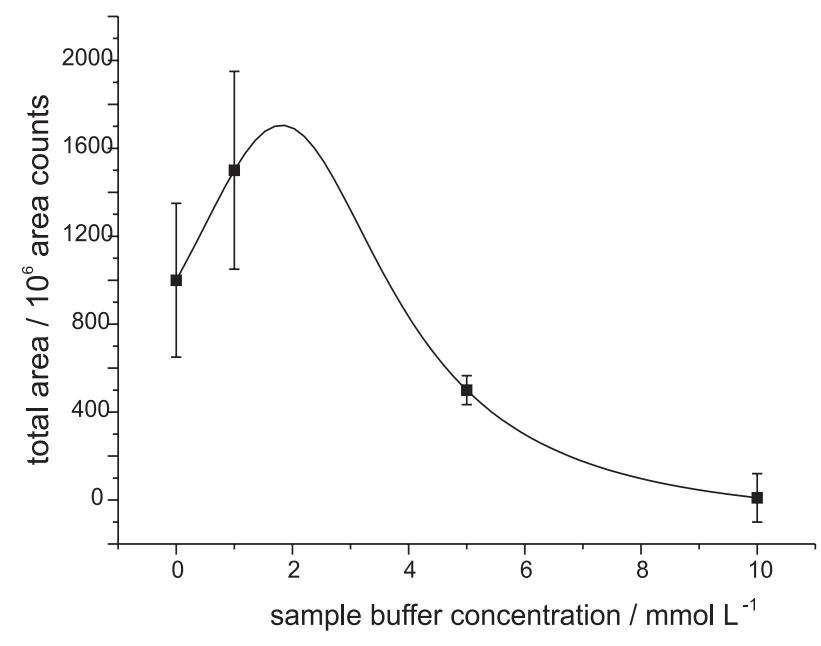

Figure 6. Total peak area for electrokinetic injections of 1-kbp DNA ladder as a function of the sample buffer concentration. Analysis conditions were the same as in Figure 5 except the number of replicates, which varied from four to six.

concentration. Nevertheless, it is fair to state that a $100 \mu \mathrm{g} \mathrm{mL}^{-1}$ DNA sample injected under the same conditions would present a maximum signal, i.e., a signal which represents the maximum amount of DNA injected, at about 1-2 mmol L $\mathrm{L}^{-1}$ of buffer in the sample matrix. However, due to the high detectability obtained by the LIF detection even small amounts of ethidium bromideintercalated DNA produce enough signal for a satisfactory detection for the sample diluted in 5.0 or $10 \mathrm{mmol} \mathrm{L}^{-1}$ buffer. Despite the low signal intensity, the separation efficiency was great and the resolution of peaks was possible over $10 \mathrm{kbp}$ range.

\section{Sample aging vs. separation matrix aging}

In the experiment reported in Figure 3, both sample and the separation matrix were kept the same, with both being reused, injection after injection. In order to identify and isolate the contribution of each, two additional experiments were conducted using samples diluted in 1.0 mmol L-1 and their results are shown in Figure 7. In the first one (Figure 7A), a new sample aliquot was used for repeated injections on the same separation matrix. In the second experiment (Figure 7B), the same sample aliquot was used repeatedly but the sieving matrix was replaced and conditioned after every run. Reuse of the separation matrix was more damaging to the separation than reusing the sample. Injection after injection there was a decrease in the current during injection, thus introducing less DNA into the column. This behavior was reflected during the whole analysis time with an unstable current and lower values after each consecutive run. The data for the electrokinetic injections are shown in Table 1. It is possible 
Table 1. Injection current and quantity of DNA injected for four consecutive runs using the same polymer solution in the capillary and exchanging the sample aliquot. A constant $50 \mathrm{~V} \mathrm{~cm}^{-1}$ electric field was applied for $20 \mathrm{~s}$ during EK injection

\begin{tabular}{lcccc}
\hline Run \# & $\begin{array}{c}\text { Injection Current } \\
(\mu \mathrm{A})\end{array}$ & $\begin{array}{c}\text { Total Charge } \\
(\mu \mathrm{C})\end{array}$ & $\begin{array}{c}\text { Quantity of DNA } \\
\text { Injected }(\mathrm{pmol})\end{array}$ & $\begin{array}{c}\text { Quantity of DNA } \\
\text { Injected (ng) }\end{array}$ \\
\hline First & 4.5 & 90 & 450 & 290 \\
Second & $2.0-4.0$ & $40-80$ & $200-400$ & $130-260$ \\
Third & $2.0-3.0$ & $40-60$ & $200-300$ & $130-195$ \\
Fourth & $1.0-1.5$ & $20-30$ & $100-150$ & $65-98$ \\
\hline
\end{tabular}

a To calculate the DNA mass injected, an average molar mass of $650 \mathrm{~g} \mathrm{~mol}^{-1}$ per bp was used.
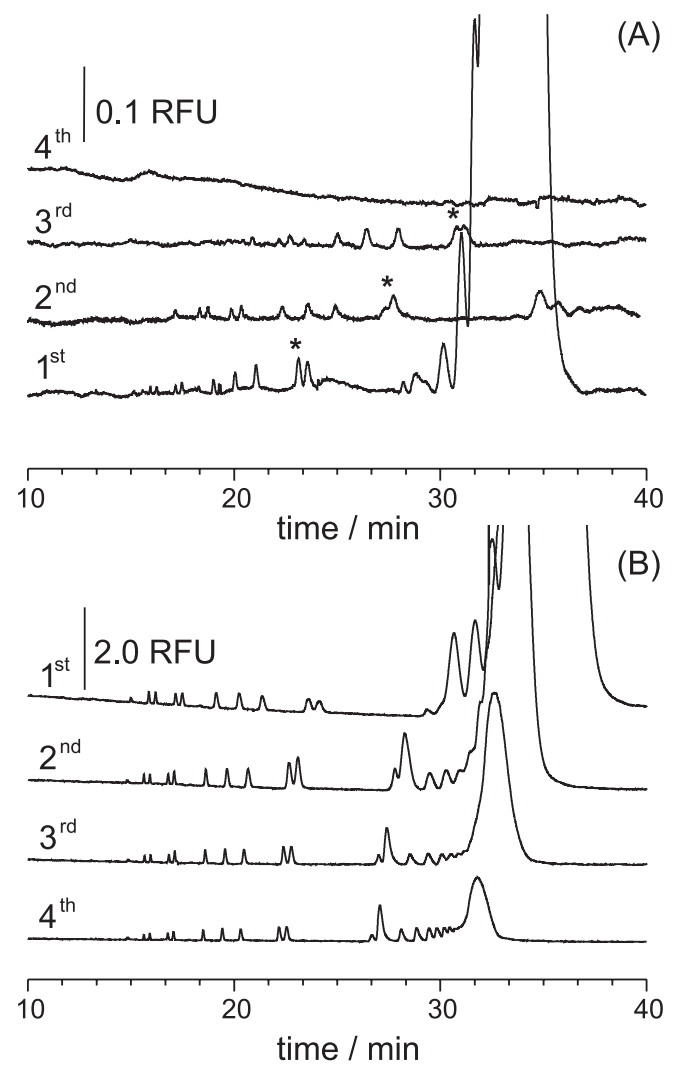

Figure 7. Separation of 1-kbp DNA ladder in repetitive injections. A) Four aliquots of sample were injected in the same separation matrix. The 506/517 bp peak pair were labeled with an * for clarity. B) An aliquot of sample was injected repeatedly in four loads of fresh sieving polymer solution. Analysis conditions were the same as in Figure 1, except the sample buffer concentration, which was $1.0 \mathrm{mmol} \mathrm{L}^{-1}$ in all cases.

to note that the quantity of DNA injected in the fourth run is less than $30 \%$ the first one, an indication that the polymeric solution lost its conductivity, which led to a drop in the electric current also during analysis. It is interesting to note that, although there was a small current during the fourth injection, no peaks were detected (Figure $7 \mathrm{~A})$.

When reusing the sample aliquot but replacing the separation matrix it was possible to obtain reproducible separation times and efficiencies (Figure 7B). There was a small decrease in the total peak area due to sample consumption, observed as the decrease of the biasedreptation peak (the last peak in the separation). Additionally, there could also be some sample buffer contamination with electrolytes and electrolysis products, increasing the sample conductivity and the larger DNA were less favored during injection (note the decrease in the biased-reptation peak area). Similar results were observed when the sample buffer concentration was varied from zero (deionized water) to $10 \mathrm{mmol} \mathrm{L}^{-1}$ (Figure 6). In desalted sample, the biased-reptation peak was about $95 \%$ of the total peak area while in $10 \mathrm{mmol} \mathrm{L}^{-1}$ this peak was about $40 \%$ of the total integrated area. This was an indication that at lower buffer concentration, i.e., at lower ionic strength, the larger DNA were responsible for carrying most of the electric current, thus being preferentially injected. Such findings agreed with those reported by SalasSolano et al. ${ }^{31}$

Although it may appear that quantitative injections of DNA in CE with polymer solutions were not reliable, we have conducted a intermediate precision study in which eight runs, on two different days, were taken into account for migration time and peak area variability. The specific conditions for the analysis were optimized by a six-variable modified simplex method (Catai and Carrilho, unpublished results) and the separation was carried out in $0.26 \%$ HEC in TTE buffer at $260 \mathrm{~V} \mathrm{~cm}^{-1}$ and $25.9{ }^{\circ} \mathrm{C}$. The sample was diluted in $0.6 \mathrm{mmol} \mathrm{L}^{-1}$ TTE buffer and injected for $19 \mathrm{~s}$ at $97.5 \mathrm{~V} \mathrm{~cm}^{-1}$. Both sample and separation matrix were fresh for every injection and the average RSD for migration time and peak area was $<4 \%$ for each peak in the sample.

\section{Conclusions}

With a close look at the results is possible to note that the composition of the sample is one of the main factors that affect the resolution, signal intensity, and the reproducibility. However, the condition of the polymeric solution also has shown a strong influence, mainly in the amount of DNA injected and the mobility of the DNA fragments. Replacement of the separation matrix is simple 
and is not worth compromising the results with its reuse. Interestingly, the overlapping of these two factors (reuse of sample and separation matrix) in a deionized sample was not so critical. Even after the sixth run without replacing both the sample aliquot and the polymeric solution DNA was still entering in the column (Figure 3 ). The composition of the sample should present a buffer concentration between 1.0 and $5.0 \mathrm{mmol} \mathrm{L}^{-1}$ for reproducible injection and separation. The polymeric solution must be replaced before each analysis due to the drop in the electric current by electrolyte depletion during electrophoresis, which decreased the conductivity.

\section{Acknowledgments}

The authors thank the Fundação de Amparo à Pesquisa do Estado de São Paulo - FAPESP, for financial support under the grant number 98/12385-2, and the Conselho Nacional de Desenvolvimento Científico e Tecnológico CNPq, for a scholarship (J.R.C.) and a fellowship (E.C.).

\section{References}

1. Issaq, H. J.; Electrophoresis 2000, 21, 1921.

2. Cohen, A. S.; Najarian, D. R.; Paulus, A.; Guttman, A.; Smith, J. A.; Karger, B. L.; Proc. Natl. Acad. Sci. USA 1988, 85, 9660.

3. Heiger, D. N.; Cohen, A.S.; Karger, B.L.; J. Chromatogr. 1990, 516,33

4. Grossman, P. D.; Soane, D. S.; J. Chromatogr. 1991, 559, 257.

5. Pariat, Y.F.; Berka, J.; Heiger, D. N.; Schmitt, T.; Vilenchik, M.; Cohen, A. S.; Foret, F.; Karger, B. L.; J. Chromatogr. A 1993, 652, 57.

6. Chang, H. T.; Yeung, E. S.; J. Chromatogr. B 1995, 669, 113.

7. Gao, Q. F.; Yeung, E. S.; Anal. Chem. 1998 70, 1382.

8. Chiari, M.; Cretich, M.; Horvath, J.; Electrophoresis 2000, 21, 1521.

9. Maschke, H. E.; Frenz, J.; Belenkii, A.; Karger, B. L.; Hancock, W. S.; Electrophoresis 1993, 14, 509.
10. Chiari, M.; Cretich, M.; Consonni, R.; Electrophoresis 2002, 23,536 .

11. Barron, A. E.; Soane, D. S.; Blanch, H. W.; J. Chromatogr. A 1993, 652, 3; Dolnik, V.; Gurske, W. A.; Electrophoresis 1999, $20,3373$.

12. Mitnik, L.; Salome, L.; Viovy, J. L.; Heller, C.; J. Chromatogr. A 1995, 710, 309.

13. Chiari, M.; Damin, F.; Melis, A.; Consonni, R.; Electrophoresis 1998, 19, 3154.

14. Chang, H. T.; Yeung, E. S.; J. Chromatogr. B 1995, 669, 113.

15. Gao, Q. F.; Yeung, E. S.; Anal. Chem. 1998, 70, 1382.

16. Müller, O.; Minarik, M.; Foret, F.; Electrophoresis 1998, 19, 1436.

17. Madabhushi, R. S.; Vainer, M.; Dolnik, V.; Enad, S.; Barker, D. L.; Harris, D. W.; Mansfield, E. S.; Electrophoresis 1997, $18,104$.

18. Mitnik, L.; Salomé, L.; Viovy, J. L.; Heller, C.; J. Chromatogr. A 1995, 710, 309 .

19. Heller, C.; Electrophoresis 1998, 19, 1691.

20. Heller, C.; Electrophoresis 1998, 19, 3114

21. Heller, C.; Electrophoresis 1999, 20, 1962.

22. Heller, C.; Electrophoresis 1999, 20, 1978.

23. Heller, C.; Electrophoresis 2001, 22, 629.

24. Krivácsy, Z.; Gelencser, A.; Hlavay, J.; Kiss, G.; Sárvári, Z.; J. Chromatogr. A 1999, 834, 21.

25. Giddings, J. C.; Unified Separation Science, Wiley: New York, 1991.

26. Grossman, P. D.; Colburn, J. C.; Capillary Electrophoresis, Theory and Practice, Academic Press: San Diego, 1992.

27. Spencer, M.; Kirk, J. M.; Electrophoresis 1983, 4, 46.

28. Rose, D. J.; Jorgenson, J. W.; Anal. Chem. 1988, 60, 642.

29. Slater, G. W.; Noolandi, J.; Phys. Rev. Lett. 1985, 55, 1579.

30. Catai, J. R.; Carrilho, E.; Electrophoresis 2003, 24, 648.

31. Salas-Solano, O.; Ruiz-Martinez, M.C.; Carrilho, E.; Kotler, L.; Karger, B.L.; Anal. Chem. 1998, 70, 1528.

Received: March 11, 2003

Published on the web: May 10, 2004

FAPESP helped in meeting the publication costs of this article. 